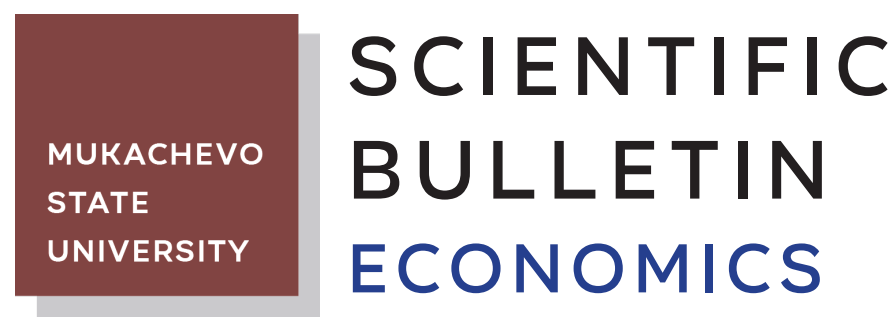

Volume 8, No. 4, 9-18

Journal homepage: https://economics-msu.com.ua/en

UDC $330 / 519.8$

DOI: 10.52566/msu-econ.8(4).2021.9-18

\title{
Methodology for Rationalising the Distribution of Limited Material Resources Considering the Importance and Initial Adequate Supply of Facilities
}

\author{
Volodymyr V. Herasymenko*, Julia O. Lutsyk, Pavlo P. Parhomenko, \\ Olexander M. Demenev, Volodymyr I. Mirnenko
}

\author{
The National Defence University of Ukraine named after Ivan Cherniakhovskyi \\ 03049, 28 Povitroflotskyi Ave., Kyiv, Ukraine
}

\begin{abstract}
The organisation of resource support for the needs of the Armed Forces of Ukraine is an important daily task related to the distribution of material resources for their intended purpose. If there is a sufficient resource base and the factors of time, speed, and priority of delivery of funds are secondary, resource support is carried out according to the principles "if necessary" and "if possible". However, the practices of resource support for the needs of the Armed Forces of Ukraine considering the limited resource capabilities of the national economy and other similar tasks, as a rule, demonstrates the necessity of acting in the conditions of quantitative and qualitative restrictions of the resource base. Moreover, in the conditions of requirements for reducing the time of implementation of resource support, considering the priority of resource assignment objects and different levels of their initial resource provision. The purpose of this study is to find the best, rational, and even optimal distribution of resources for certain characteristics in three types of business conditions: certainty, uncertainty, and risk in managerial decision-making. Based on the analysis of available methods of nonlinear programming in distribution problems, proceeding from the condition of maintaining mathematical correctness and accessibility to practical use, the study presents the procedure for applying the maximum element method. The proposed approach to optimising the distribution problem is considered on the example of possible distribution options for equally efficient resource supply between the resource supply facilities. The options differ in the values of the importance of objects and the levels of initial supply in relative units at the time of decision-making on the allocation of resources upon providing resources for a certain final management task. The methodology of this study can be used in planning and decision-making related to the distribution of resources in organisational systems of military and civil administration, considering the importance and initial state of adequate supply of destination facilities in case of limited capabilities of the resource manager
\end{abstract}

Keywords: resource provision, priority of destination objects, rational allocation of resources, maximum element method, planning

Received: 15.08.2021, Revised: 14.09.2021, Accepted: 18.10 .2021

Suggested Citation: Herasymenko, V.V., Lutsyk, Ju.O., Parhomenko, P.P., Demenev, O.M., \& Mirnenko, V.I. (2021). Methodology for rationalising the distribution of limited material resources considering the importance and initial adequate supply of facilities. Scientific Bulletin of Mukachevo State University. Series “Economics", 8(4), 9-18.

${ }^{*}$ Corresponding author 


\section{Introduction}

The foundations of the state's defence capability and military security are created by its armed forces. The combat readiness and combat capability of the Armed Forces of Ukraine are largely dependent on the quantitative and qualitative level of their supply and technical equipment. The activities of state and military administration bodies related to the technical equipment of the Armed Forces and other law enforcement agencies are performed through the implementation of the national military-technical policy. Therefore, the military-technical policy of the state is interpreted as a directed and coordinated activity of state authorities and military administration, based on the system of conceptual opinions adopted in the state regarding military-technical support for the national defence and military security. The military-technical policy is aimed at practical solutions to the problems of providing the Armed Forces, other troops and military formations with weapons, military and special equipment, ammunition and property, and the development of the technological capability of the national military-industrial complex. The quantitative and qualitative composition of weapons and military equipment created in the process of implementing national programmes for the development of the Armed Forces is determined by the state and capabilities of the national economy, technological, production engineering potentials of the industry. For the purposes of this paper, the capabilities of the national economy to supply the Armed Forces of Ukraine mean its ability to meet the needs of the Armed Forces, maintain and develop weapons systems and their comprehensive support by maintaining and restructuring the military-industrial complex and developing an $\mathrm{R} \& \mathrm{D}$ and manufacturing base for the production of modern and promising weapons and military equipment.

The main tool for conducting military-technical policy is the rational use of the national economic capabilities, the rational distribution and redistribution of financial and material resources allocated by the state between various spheres of the military economy, the main areas of which are as follows:

- technological, with the creation of new and modernisation of available weapons and military equipment;

- manufacturing, related to the production of weapons and military equipment and military property;

- logistics, the content of which is the creation and maintenance of the necessary infrastructure and reserves for the functioning of troops (forces) in peacetime and wartime;

- ensuring the mobilisation readiness of industry and other economy sectors.

Resource support for the implementation of militarytechnical policy is provided from two groups of resources:

- resources allocated for ensuring the life and combat readiness of the Armed Forces of Ukraine;

- resources aimed at developing the economy sectors that produce both military products and social and economic products in the interests of the Armed Forces.
The main types of resources for ensuring military-technical policy include material (material and technical), human, and financial resources. Recently, information resources have also been classified in the above group. Providing military-technical policy with material resources is the process of supplying the Armed Forces of Ukraine with weapons and military equipment, ammunition, fuel and lubricants, clothing, medical, technical property, etc. At the same time, the military-industrial complex is equipped with high-tech materials and raw materials.

The continuous complication of modern weapons and military equipment is conditioned upon many objective reasons and leads to a considerable increase in their cost. This increases the importance of economic factors, the cost of military products, comparing with purely military factors when making appropriate decisions on the vectors of military construction in general and on the development vectors of the Armed Forces of Ukraine and their weapons systems, on the rationality and validity of defence spending. The development of means of supplying the Armed Forces, primarily complex weapons systems, is beginning to be dominated by the economic feasibility of using defence spending, the priority of economic factors, comparing with military-strategic, increasing attention to the effective use of the capabilities of enterprises of the military-industrial complex and the national economy in general to solve defence problems. The measures carried out in the organisation of resource supply for the needs of the Armed Forces of Ukraine include measures related to the distribution of material and technical supplies for military facilities. If the base for collateral is sufficient, and the factors of time, speed, and order of delivery of funds are of secondary importance, supply can be provided "if needed" and "if possible".

The theory and practice of ensuring the performance of tasks, including resource support, of the troops (forces) of the Armed Forces of Ukraine considering the limited resource capabilities of the national economy [1-3] clearly indicate that it is usually necessary to act in conditions of certain resource restrictions, and, moreover, in conditions of strict time requirements for the implementation of resource support, factoring in the importance of objects of the intended purpose of resources, different levels of their initial supply and legislative framework. Thus, the purpose of this study lies in finding the best allocation of available limited resources in predictable and unpredictable conditions for managerial decision-making.

\section{Literature Review}

The practice of resource support has demonstrated that as a rule, for most software tasks, restrictions on resource support factors, relationships between resource consumption objects are nonlinear in nature, and therefore nonlinear programming methods are used to solve problems of this class. 
The analysis of mathematical methods used to solve problems of limited resource allocation, namely nonlinear programming methods, and the condition for maintaining mathematical correctness and accessibility to practical use among practitioners, allowed focusing on one of the numerical methods of nonlinear programming [4], namely the maximum element method [5-7]. Thus, the study of Y.M. Cheng and C.K. Lau evaluates the fundamental assumptions and limitations of stability analysis and computer modelling methods, namely upon applying the maximum element method [5]. The best developments of Ukrainian researchers "consider mathematical methods for studying economic processes under the influence of random factors, mastering which will allow systematising the knowledge and practical skills in economic and statistical modelling and forecasting" [8]. The fundamentals of optimal control theory, which are used to solve the problem of limited resource allocation and its application in the study of economic and mathematical models, are described in the study of V.S. Hryhorkiv [9]. Systematic coverage of calculations and matrix algebra, probability, optimisation, and dynamics with an emphasis on intuitive argument and problemsolving is covered by M. Pemberton and N. Rau [10]. Examples of practical solutions to problems, namely those related to the allocation of a limited resource, are given in the developments of E. Dowling [11]. The third chapter describes the theory of optimal control using linear algebra, differential and integral calculations, nonlinear programming, differential and difference equations, and calculus of variations. It also offers a brief overview of basic algebra for practical application to everyday economic problems and business situations.

The study of N. Boyko et al. proposes an approach to analysing the behaviour and predicting the location of an object for the following month using clustering algorithms [12]. The study also considers the problem of finding associative rules. The authors used scalable Apriori algorithms to find the best rules. At the same time, the problem of the search for associative rules that could find and describe patterns in large data sets is considered, which is advisable to use upon rationalising the distribution of limited material resources, considering the importance and initial state of supply of military facilities [12]. Furthermore, the study presents shortcomings concerning the problem of inaccuracy and inconsistency of data with real conditions, which affects the feasibility of applying associative rules to search for patterns in processes.

The study [13] provides the ways to improve production and economic systems to increase the efficiency of functioning of economic facilities and achieve high, final results of activity based on the rational use of resources of production activities of the enterprise. It is determined that the main purpose of resource management for enterprises is their optimisation. The study substantiates the importance of determining the optimal need for resources and ensuring the structure of sources of its formation and use for the effective performance of an individual enterprise. The mathematical models and methods proposed in the paper [14] constitute effective mechanisms for forecasting, synthesis and analysis, and management support in the relevant areas of economic application. The developed methods and models are brought to practical implementation in the form of software that are reliable tools for solving problems of business forecasting, assessment and management of the development of economic processes and systems. The study [15] investigates the essence and significance of using methods of economic and mathematical modelling in managing the development of economic systems at the macro level using a systematic approach, and proposes approaches to ensure the adequacy of the development of economic and mathematical models that allow obtaining forecast values of the necessary indicators.

\section{Materials and Methods}

These tasks relate to the problems of choosing the optimal $X_{i}$ option from a certain set $X$ of possible options, $X_{i} \in X$. Each solution option $X_{i}$ is a vector of controlled variables. This vector uniquely defines some final result with a quantitative estimate, which mostly corresponds to the value of the formed (selected) objective function. Such problems are solved by mathematical programming methods, which contribute to the choice of a solution that provides the maximum (minimum) value of the objective function of the effect.

The maximum element method belongs to gradient methods. Its main advantage is that it solves problems with numerous variables $n$ reduced to a sequential solution of $n$ tasks with a single variable. According to the algorithm of the method, only one unit of a discrete resource is distributed at each arbitrary step of the optimisation. This means that on each $t$-th iteration step $(t=1, \ldots, d)$, a single increment is provided $\left(\Delta X_{i}=1\right)$ to only one $i$-th variable of the optimal vector $X_{0}=\left\{x_{i}^{0}\right\} n$, which is an option of allocating the homogenous resource. After a finite number of steps $d$, which is equal to the number of units of the $n$ resource, equal supply distribution, the entire resource $N$ is optimally distributed among consumers.

In general, the problem statement can be formulated as follows. The task is to find the optimal vector $X_{0}=\left\{x_{i}^{0}\right\} n$, which directs the target function (1):

$$
F(X)=\sum_{i=1}^{S} F_{i}\left(x_{i}\right)=\sum_{i=1}^{S} A_{i}\left(1-\varepsilon_{i}^{x_{i}}\right)
$$

to the maximum, with linear constraints on its components (2):

$$
\sum_{i=1}^{n} x_{i} \leq N
$$


and additional conditions (3):

$$
\begin{aligned}
& x_{i} \in\{0,1, \ldots, N\}, \\
& \left.\begin{array}{rl}
0 & \leq\left(\varepsilon_{i}=1-\omega_{i}\right) \leq 1, \\
A_{i} & >0,
\end{array}\right\} \quad i=1, \ldots, S
\end{aligned}
$$

After opening the parentheses, one gets (4):

$$
F\left(X_{0}\right)=\max _{X} F(X)=\sum_{i=1}^{S} A_{i}-\min _{X} \sum_{i=1}^{S} A_{i} \varepsilon_{i}^{x_{i}} \sim \min _{X} \sum_{i=1}^{S} A_{i} \varepsilon_{i}^{x_{i}}
$$

That is, the task of maximising the objective function $F(X)$ is equivalent to the function minimisation problem (5):

$$
\bar{F}(X)=\sum_{i=1}^{S} A_{i} \varepsilon_{i}^{x_{i}}
$$

To solve the problem of resource provision using the method of the maximum element, the former can be formulated as follows. There is a certain amount of resource $N$, which, to perform resource supply tasks, must be distributed among several $i=1, \ldots, S$ resource-consuming facilities. Each of the facilities has a relative importance (weighting factor) $A_{i}$ from the standpoint of participation in the performance of the final task for which resources are supplied (e.g., tasks for mobilisation training, bringing to combat readiness, etc.). Resource $N$ can come from a higher authority of management or in separate identical batches (units) $X_{i}$, or in its entire volume, but can be consumed by facilities as separate batches $X_{i}$. Each batch (unit) of the resource ensures that the facility performs the final task with probability $\varpi_{i}=1-\varepsilon_{i}$, where $\varepsilon_{i}=1-\varpi_{i}$ is the conditional probability of not supplying the resource to the facility. It is necessary to find a method of distributing resource supply funds by resource-consuming facilities, where the maximum distribution effect is achieved (total resource usage, time of use, speed of use). Therewith, $\varpi_{i}$ can be interpreted as the relative need for resource supply of the final task and determined according to the following formula (6):

$$
\omega_{i}=\frac{W_{i}}{\sum_{i=1}^{S} W_{i}}=\frac{T_{i}}{\sum_{i=1}^{S} T_{i}}=\frac{V_{i}}{\sum_{i=1}^{S} V_{i}}
$$

where $W_{i}$ is the required task volumes for $i$-th supply facility; $T_{i}$ is the required time to complete the task on the $i$-th supply facility; $V_{i}$ is the required pace of completing the task on the $i$-th supply facility.

Maximising the overall effect $F(X)$ is equivalent to maximising the average value based on one of the $i$-th resource batch $N$, that is (7):

$$
\max _{X} F(X) \sim \max _{X}\left\{\frac{F(X)}{N}=v(X)\right\}
$$

The average effect $v(X)$ based on one of the $N$ will be the maximum supply amount if at each stage of the process one of the active supplies is assigned to the supply facility $i$, where the effect increment at this step $\left(\Delta_{\mathrm{i}}\right)$ is maximum.
Such an algorithm for allocating a resource across facilities to achieve the maximum effect can be considered justified, since each of the functions $F_{i}\left(x_{i}\right)$ is convex upwards and forms a descending sequence of effect increments $\left(\Delta_{i}\right)$ from the influence of each subsequent batch (8):

$$
\begin{gathered}
F\left(x_{i}\right)=A_{i}\left(1-\varepsilon_{i}^{x_{i}}\right)=A_{i} \omega_{i}+A_{i} \varepsilon_{i} \omega_{i}+\ldots+A_{i} \varepsilon_{i}^{x_{i}-1} \omega_{i}^{*}= \\
=\Delta_{1 i}+\Delta_{2 i}+\ldots+\Delta_{i}=\sum_{k=1}^{x_{i}} \Delta_{k i}, \quad \Delta_{k i}=A_{i} \varepsilon_{i}^{k-1} \omega_{i}
\end{gathered}
$$

hence it allows the resource to be distributed in the same minimum (single) portions on one side, and due to the same type (uniformity) of batches, no mutual replacement of any two of their units is required.

After covering the approach to solving the problem, it remains to determine the expression for calculating the increment value $\Delta_{l}$ of the objective function, which it obtains on an arbitrary $t$-th stage of the optimisation. By the time of appointment of the $x$-th resource unit on the $t$-th first step of the process, $(t-1)$ units have already been distributed, and the $i$-th facility is supplied with certain probability $P_{i}^{(t-1)}(i=1, \ldots, S)$, i.e., at this point, the value of the objective function can be written as follows (9):

$$
F_{t-1}=\sum_{i=1}^{S} A_{i} P_{i}^{(t-1)}
$$

After the appointment of the $x$-th unit (resource) to $l$-th facility $(l=1, \ldots, S)$, the current value of the objective function will increase only when the $l$-th faclity increases the effect and will be as follows (10):

$$
F_{t}=\sum A_{i} P_{i}^{(t-1)}+A_{l}\left(1-Q_{l}^{(t-1)} \varepsilon_{l}\right)
$$

where $Q_{l}^{(t-1)}=1-P_{l}^{(t-1)}$ is the probability of failure in terms of resources of the $l$-th object to the appointment of the $t$-th batch of means; $\varepsilon_{l}=1-\omega_{l}$ is the conditional probability of non-provision of the $l_{-}{ }^{\text {th }}$ facility in terms of resources be the $t$-th batch.

Adding and subtracting agent $A_{l} P_{l}^{(t-1)}$ from the right-hand side of Eq. (9) and considering Eq. (10), one obtains as follows (11):

$$
F_{t}=F_{t-1}+A_{l}\left(1-Q_{l}^{(t-1)} \varepsilon_{l}\right)-A_{i} P_{i}^{(t-1)}
$$

The increment after elementary transformations is written as follows (12):

$$
\Delta_{l}=F_{t}-F_{t-1}=A_{l} Q_{l}^{(t-1)} \omega_{l}=A_{l}^{(t-1)} \omega_{l}, l=1, \ldots, \quad S
$$

If $A_{1}$ is the initial weight coefficient of the facility, then $A_{l}^{(t-1)}=A_{l} Q_{l}^{(t-1)}$ is its weight after distribution $(t-1)$ of supply units.

The algorithm of sequential actions (steps) of optimising the resource allocation based on the selected maximum element method can be presented in the form of the flowchart presented in Figure 1. 


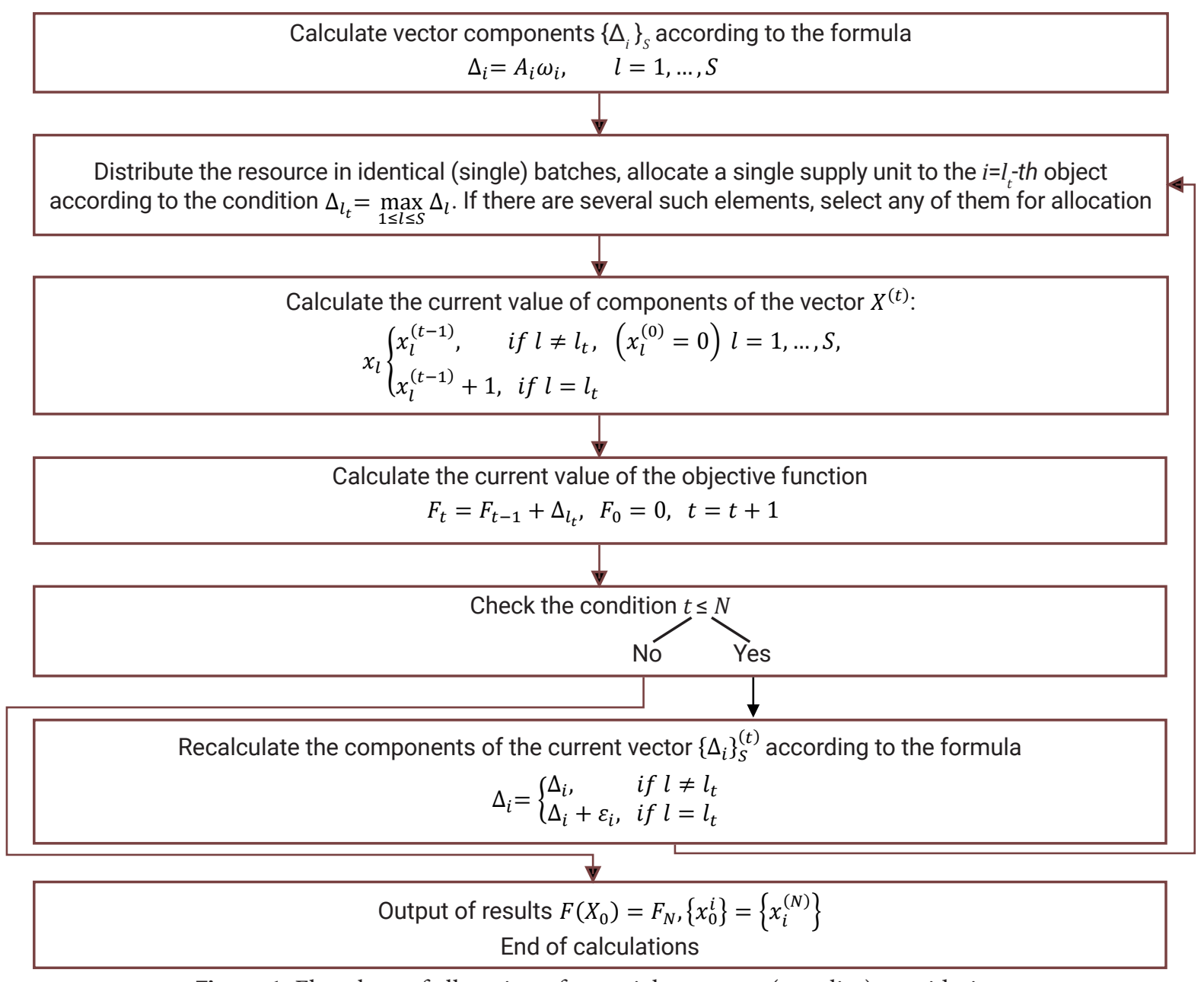

Figure 1. Flowchart of allocation of material resources (supplies) considering the importance and initial adequate supply of military facilities

According to the algorithm of the method, only one unit of a discrete resource is distributed at each subsequent step of the optimisation. This means that on each $t$-th iteration step $(t=1, \ldots ., d)$, a single increment is provided $\left(\Delta X_{i}=1\right)$ to only one $i$-th variable of the optimal vector $X_{0}=\left\{x_{i}^{0}\right\} n$, which constitutes an option of allocating the homogenous resource between $n$ consumers. After a finite number of steps $d$, which is equal to the number of units of the $n$ resource, the entire resource is optimally distributed among consumers.

To distribute a multi-efficient resource using the proposed methodology, supply resources should be divided into equal batches in terms of efficiency (productivity, and other qualitative characteristics). The resource should be distributed by supply facilities in batches. At the same time, the sequence of batch changes should be carried out towards reducing the efficiency (productivity, quality capabilities) of the resource's funds. There may be situations when for all supply facilities the volumes of tasks must be not lower than admissible for obligatory maximisation of target function.

In such cases, the above algorithm allows justifying the amount of supply resources required to achieve the goal of the final task. In this case, the initial number of batches of resource $N$ is not limited, and the resource allocation continues until the total volume of tasks for all supply facilities meets the specified limit. The number of batches of the resource that ensures the achievement of the goal is assumed to be equal to the number of distribution steps, that is, $N=t$.

\section{Results and Discussion}

The proposed approach to optimising the distribution problem is considered on the example of three possible distribution options for equally efficient resource supply between five resource supply facilities. The options vary in different priority values $A_{i}$ of objects on a ten-point scale of the final resource supply and different levels of initial supply in relative units (percentages) at the time of decision-making on the allocation of resources upon supplying resources for a certain final management task. It is assumed that data on the priority and level of initial adequate supply of resources are determined either by a group of expert officials or by a decision-maker. The solution result for the first option is presented in Table 1. 
Table 1. The first option of rational distribution of 7 resource means between 5 facilities

\begin{tabular}{|c|c|c|c|c|c|c|}
\hline \multicolumn{7}{|c|}{ Resource allocation facilities $i=1, \ldots, S$} \\
\hline \multirow{5}{*}{$\begin{array}{l}\text { Step of the } \\
\text { sequential } \\
\text { resource } \\
\text { allocation } \\
t=1, \ldots, N\end{array}$} & 1 & 2 & 3 & 4 & 5 & \multirow{5}{*}{$\begin{array}{c}\text { Objective } \\
\text { function } F_{t} \\
\text { of effect of } \\
\text { using the } \\
\text { resource }\end{array}$} \\
\hline & \multicolumn{5}{|c|}{ Importance (priority) of the facility, weight coefficient $A_{i}$} & \\
\hline & 2 & 6 & 10 & 4 & 8 & \\
\hline & \multicolumn{5}{|c|}{ Resource availability (facility status) indicators $\omega_{i}$} & \\
\hline & 0.6 & 0.5 & 0.5 & 0.4 & 0.6 & \\
\hline \multicolumn{7}{|c|}{ Increment $\Delta_{i}$ of effect of using a resource for a facility $i, \Delta x_{i}$} \\
\hline 1 & $1.2 / 0$ & $3 / 0$ & $5 / 1$ & $1.6 / 0$ & $4.8 / 0$ & 5 \\
\hline 2 & $1.2 / 0$ & $3 / 0$ & $2.5 / 0$ & $1.6 / 0$ & $4.8 / 1$ & 9.8 \\
\hline 3 & $1.2 / 0$ & $3 / 1$ & $2.5 / 0$ & $1.6 / 0$ & $1.92 / 0$ & 12.8 \\
\hline 4 & $1.2 / 0$ & $1.5 / 0$ & $2.5 / 1$ & $1.6 / 0$ & $1.92 / 0$ & 15.3 \\
\hline 5 & $1.2 / 0$ & $1.5 / 0$ & $1.25 / 0$ & $1.6 / 0$ & $1.92 / 1$ & 17.22 \\
\hline 6 & $1.2 / 0$ & $1.5 / 0$ & $1.25 / 0$ & $1.6 / 1$ & $0.77 / 0$ & 18.82 \\
\hline 7 & $1.2 / 0$ & $1.5 / 1$ & $1.25 / 0$ & $0.96 / 0$ & $0.77 / 0$ & 20.32 \\
\hline$\Sigma \Delta_{i} / \Sigma \Delta x_{i}$ & $0 / 0$ & $4.5 / 2$ & $7.5 / 2$ & $1.6 / 1$ & $6.72 / 2$ & 20.32 \\
\hline
\end{tabular}

At the first step (Table 1), the values of effect increments $\left(\Delta_{i}\right)$ are calculated as a product $A_{i} \varpi_{i}$. The maximum increment of the effect at this step is given by allocating a resource supply unit to the third facility $x_{3}=1, \Delta_{3}=5, F_{1}=5$ The resource supply is not assigned to all other facilities at this step. At the second step, the effect increment values for all facilities, except the third, remain the same (they did not change at the first step), and when determining the effect increment for the third object, the conditional execution of the required volumes of tasks by one supply batch at the first step is factored in, that is, $\Delta_{3}=A_{3}\left(1-\varpi_{3}\right) \varpi_{3}$. The maximum increment of the effect at the second step is given by allocating resources to the fifth facility $x_{5}=1, \Delta_{5}=4.8$. The value of the objective function is $F_{2}=F_{1}+\Delta_{5}=5+4.8=9.8$. Continuing to perform a consistent distribution of resource funds by collateral objects in this fashion up to $t=7$, one gets the result of solving the problem using the maximum element method. At each step (Table 1), elements that are considered at every step of the resource allocation are highlighted in bold. The last line indicates the total effect for each facility and the total number of supply batches allocated to these facilities. For supply facilities that were not allocated funds, the total effect is zero. Therefore, the maximum value of the objective function during the allocation of seven resources is $F_{7}=20.32$. At the same time, funds for collateral objects are distributed as follows: $x_{1}=0, x_{2}=2, x_{3}=2, x_{4}=1, x_{5}=2$. Therefore, the first object is not supplied at all, and this should be taken into account upon analysing the results of calculations performed.

The solution result for the second option is presented in Table 2 and the third option is presented in Table 3.

Table 2. The second option of rational distribution of 7 resource means between 5 facilities

\begin{tabular}{|c|c|c|c|c|c|c|}
\hline \multicolumn{7}{|c|}{ Resource allocation facilities $i=1, \ldots, S$} \\
\hline \multirow{5}{*}{$\begin{array}{l}\text { Step of the } \\
\text { sequential } \\
\text { resource } \\
\text { allocation } \\
t=1, \ldots ., N\end{array}$} & 1 & 2 & 3 & 4 & 5 & \multirow{5}{*}{$\begin{array}{c}\text { Objective } \\
\text { function } F_{t} \\
\text { of effect of } \\
\text { using the } \\
\text { resource }\end{array}$} \\
\hline & \multicolumn{5}{|c|}{ Importance (priority) of the facility, weight coefficient $A_{i}$} & \\
\hline & 8 & 4 & 10 & 6 & 2 & \\
\hline & \multicolumn{5}{|c|}{ Resource availability (facility status) indicators $\omega_{i}$} & \\
\hline & 0.6 & 0.4 & 0.5 & 0.3 & 0.6 & \\
\hline \multicolumn{7}{|c|}{ Increment $\Delta_{i}$ of effect of using a resource for a facility $i, \Delta x_{i}$} \\
\hline 1 & $4.8 / 0$ & $1.6 / 0$ & $5 / 1$ & $1.8 / 0$ & $1.2 / 0$ & 5 \\
\hline 2 & $4.8 / 1$ & $1.6 / 0$ & $2.5 / 0$ & $1.8 / 0$ & $1.2 / 0$ & 9.8 \\
\hline 3 & $1.92 / 0$ & $1.6 / 0$ & $2.5 / 1$ & $1.8 / 0$ & $1.2 / 0$ & 12.3 \\
\hline 4 & $1.92 / 1$ & $1.6 / 0$ & $1.5 / 0$ & $1.8 / 0$ & $1.2 / 0$ & 14.22 \\
\hline 5 & $0.77 / 0$ & $1.6 / 0$ & $1.25 / 0$ & $1.8 / 1$ & $1.2 / 0$ & 16.02 \\
\hline 6 & $0.77 / 0$ & $1.6 / 1$ & $1.25 / 0$ & $1.26 / 0$ & $1.2 / 0$ & 17.62 \\
\hline 7 & $0.77 / 0$ & $0.96 / 0$ & $1.25 / 0$ & $1.26 / 1$ & $1.2 / 0$ & 18.88 \\
\hline$\Sigma \Delta_{i} / \Sigma \Delta x_{i}$ & $6.72 / 2$ & $1.6 / 1$ & $7.5 / 2$ & $3.06 / 2$ & $0 / 0$ & 18.88 \\
\hline
\end{tabular}


Table 3. The third option of rational distribution of 7 resource means between 5 facilities

\begin{tabular}{|c|c|c|c|c|c|c|}
\hline \multicolumn{7}{|c|}{ Resource allocation facilities $i=1, \ldots, S$} \\
\hline \multirow{5}{*}{$\begin{array}{l}\text { Step of the } \\
\text { sequential } \\
\text { resource } \\
\text { allocation } \\
t=1, \ldots, N\end{array}$} & 1 & 2 & 3 & 4 & 5 & \multirow{5}{*}{$\begin{array}{c}\text { Objective } \\
\text { function } F_{t}{ }^{3} \\
\text { of effect of } \\
\text { using the } \\
\text { resource }\end{array}$} \\
\hline & \multicolumn{5}{|c|}{ Importance (priority) of the facility, weight coefficient $A_{i}$} & \\
\hline & 2 & 6 & 10 & 4 & 8 & \\
\hline & \multicolumn{5}{|c|}{ Resource availability (facility status) indicators $\omega_{i}$} & \\
\hline & 0.5 & 0.4 & 0.7 & 0.8 & 0.6 & \\
\hline \multicolumn{7}{|c|}{ Increment $\Delta_{i}$ of effect of using a resource for a facility $i, \Delta x_{i}$} \\
\hline 1 & $3 / 0$ & $2 / 0$ & $5.6 / 0$ & $3.2 / 0$ & $6 / 1$ & 6 \\
\hline 2 & $3 / 0$ & $2 / 0$ & $5.6 / 1$ & $3.2 / 0$ & $2.4 / 0$ & 11.6 \\
\hline 3 & $3 / 0$ & $2 / 0$ & $1.68 / 0$ & $3.2 / 1$ & $2.4 / 0$ & 14.8 \\
\hline 4 & $3 / 1$ & $2 / 0$ & $1.68 / 0$ & $0.64 / 0$ & $2.4 / 0$ & 17.8 \\
\hline 5 & $1.5 / 0$ & $2 / 0$ & $1.68 / 0$ & $0.64 / 0$ & $2.4 / 1$ & 20.2 \\
\hline 6 & $1.5 / 0$ & $2 / 1$ & $1.68 / 0$ & $0.64 / 0$ & $0.96 / 0$ & 22.2 \\
\hline 7 & $1.5 / 0$ & $1.2 / 0$ & $1.68 / 1$ & $0.64 / 0$ & $0.96 / 0$ & 23.88 \\
\hline$\Sigma \Delta_{i} / \Sigma \Delta x_{i}$ & $3 / 1$ & $2 / 1$ & $7.28 / 2$ & $3.2 / 1$ & $8.4 / 2$ & 23.88 \\
\hline
\end{tabular}

The target functions of the general effect for the considered examples of resource distribution calculations depending on the priority and initial availability of destination facilities are presented in Figure 2. Evidently, each objective function of the total distribution effect is an upward-convex curve that reflects the descending sequence of the increase in the effect from each subsequent supply batch arriving at the facility.

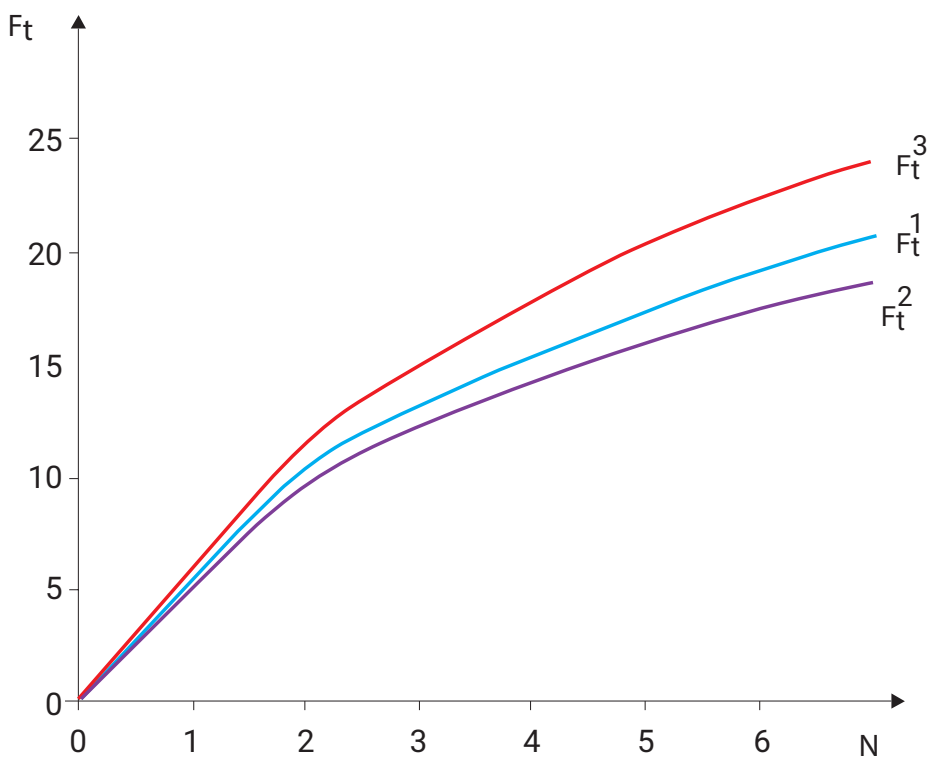

Figure 2. Objective functions of the overall effect of the three distribution options considered

Notably, the different values of the final and intermediate values of the objective functions depend solely on the initial conditions for each of the variants and do not indicate a greater or lesser comparative efficiency of a particular distribution variant.

The different quantitative nature of resource allocation (the sequence of distribution and the number of units of the received resource), depending on the importance (priority) and initial state of supply of the corresponding resourceconsuming facility, is presented in the final table (Table 4). The nature of allocation, i.e., the sequence of supplying a resource to the corresponding facility, is different and depends on the initial level of resource availability at the facility and the importance of the facility in performing the final task for which the resource supply is intended. If the total amount of the resource is inadequate, and it is in conditions of restrictions, the resource should be distributed in separate batches in a certain sequence determined according to the maximum effect algorithm. If the resource is sufficient, it can be allocated once, in batches equivalent in performance (efficiency), in the amount determined by the maximum effect algorithm under study. 
Table 4. Final table of resource allocation depending on the importance and initial state of supply

\begin{tabular}{|c|c|c|c|c|c|c|c|c|c|c|c|c|}
\hline \multirow{2}{*}{$\begin{array}{l}\text { Options } \\
\text { for possible priority and } \\
\text { initial state of supply of } \\
\text { the resource } \\
\text { supply facility }\end{array}$} & \multicolumn{7}{|c|}{$\begin{array}{l}\text { The sequence of resource allocation } \\
\text { depending on the importance } \\
\text { of the resource supply facility and the initial } \\
\text { state of its resource availability }\end{array}$} & \multicolumn{5}{|c|}{$\begin{array}{l}\text { The total number of resource units received } \\
\text { by each facility for each allocation option } \\
\text { facility number }\end{array}$} \\
\hline & \multicolumn{7}{|c|}{ facility number } & 1 & 2 & 3 & 4 & 5 \\
\hline First & 3 & 5 & 2 & 3 & 5 & 4 & 2 & 0 & 2 & 2 & 1 & 2 \\
\hline Second & 3 & 1 & 2 & 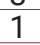 & 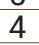 & & 4 & 2 & 1 & 2 & 2 & 0 \\
\hline Third & 5 & 3 & 4 & 1 & 5 & 2 & 3 & 1 & 1 & 2 & 1 & 2 \\
\hline
\end{tabular}

Achieving the goal of allocation according to the selected mathematical apparatus allows performing sequential, alternate bringing of equivalent resource volumes in terms of efficiency (productivity) to one of the assigned facilities, considering their needs and priority in supply. The sequence of bringing the resource to facilities should be accompanied by a decrease in the dynamics of efficiency growth from the use of the resource. This indicates that the resource is correctly represented "according to the need and priority" of the destination objects. The considered approach to optimising the problem of allocating a limited amount of resource can be extended not only to material and technical, but also to other types of resources, provided that the type of resource is adequately reflected by the corresponding unit of measurement. The approach can be considered as an accessible method for justifying management decisions when planning types of support for troops (forces). The summarising brief description of the proposed method of rational (optimal) distribution of material and technical means in conditions of a limited total resource is presented in Table 5.

Table 5. Characteristics of the methodology of optimal distribution of material and technical means in conditions of limited total resource

\begin{tabular}{cl}
$\begin{array}{c}\text { Resource type, } \\
\text { supplied by the } \\
\text { methodology }\end{array}$ & Material and technical, human, informational, financial \\
$\begin{array}{c}\text { Possible tasks from the } \\
\text { Resource Manager }\end{array}$ & $\begin{array}{l}\text { Rational distribution of the available limited resource to perform the following tasks: } \\
\text { material and technical support of troops (forces); mobilisation training of enterprises, } \\
\text { sectors of the national economy; implementation of the resource manager programme }\end{array}$ \\
\hline $\begin{array}{c}\text { Purpose of allocation } \\
\text { Selected mathematical } \\
\text { apparatus }\end{array}$ & $\begin{array}{l}\text { Optimal distribution of a limited resource in terms of time, consumer needs, and final effect } \\
\text { to achieve maximum effect in the final tasks of the resource manager }\end{array}$ \\
\hline $\begin{array}{c}\text { Applied optimisation } \\
\text { methods }\end{array}$ & $\begin{array}{l}\text { Methods of mathematical programming: optimisation methods of decision-making; } \\
\text { methods of nonlinear programming }\end{array}$ \\
\hline $\begin{array}{c}\text { The essence of the } \\
\text { of expert assessments for determining the needs (condition) of resource allocation facilities } \\
\text { and their priority in the final tasks of the resource manager }\end{array}$ \\
$\begin{array}{c}\text { allocation organisation } \\
\begin{array}{c}\text { A way to maximise the } \\
\text { overall effect of resource } \\
\text { allocation }\end{array}\end{array}$ & $\begin{array}{l}\text { Sequential, alternate bringing of equivalent efficiency (productivity) volumes (batches) of } \\
\text { a resource to one of the assigned facilities, considering their needs and priority in performing } \\
\text { the final (main) task of the resource manager }\end{array}$ \\
$\begin{array}{c}\text { Achieving the maximum overall effect of a resource by alternately bringing it to the object } \\
\text { where the maximum effect (local effect) of using the resource is achieved }\end{array}$ \\
$\begin{array}{c}\text { Feature of organising } \\
\text { the sequence of bringing } \\
\text { resources to facilities }\end{array}$ & $\begin{array}{l}\text { The sequence of bringing the resource to objects should be accompanied by a decrease } \\
\text { in the dynamics of efficiency growth from the use of the resource. This indicates that the } \\
\text { resource is presented correctly "as needed and prioritised" to effectively perform the final } \\
\text { task of the resource manager }\end{array}$ \\
\hline $\begin{array}{c}\text { Purpose of the proposed } \\
\text { methodology }\end{array}$ & $\begin{array}{l}\text { Preparation and justification of planning and decision-making options related to resource } \\
\text { allocation in organisational systems of military and civil administration }\end{array}$ \\
\hline
\end{tabular}

\section{Conclusions}

Thus, the study confirmed that the proposed methodology of optimising the distribution of equally efficient supply resources between several resource support objects allows considering different values of the priority of resource supply facilities on a ten-point scale and different levels of initial supply in relative units at any time of resource allocation. At the same time, it was discovered that a prerequisite is that data on the priority and level of initial resource availability are determined by experts or a decision-maker. It is proved that it is the options for allocating available material and technical, human, information and financial resources, 
considering the importance and initial state of supply of destination facilities in case of limited capabilities of the resource manager (and the national economy in general), that rationalise the implementation of such tasks as technical support and preparation for the actions of troops (forces); mobilisation training of enterprises of branches of the national economy; implementation of budget programmes, etc. It is summarised that the type of resource that is supplied, possible tasks from the resource manager, the purpose of distribution, the essence of the distribution organisation, the method of maximising the overall effects of resource allocation and the features of organising the sequence of resource representation on facilities are decisive upon the application of the proposed methodology, the choice of optimisation methods and the appropriate mathematical apparatus.

The methodology can be applied in planning and decision-making processes related to the allocation of resources in organisational systems of both military and civil administration.

\section{References}

[1] Decree of the President of Ukraine No. 473/2021 "On the Decision of the National Security and Defense Council of Ukraine of August 20, 2021 “On the Strategic Defense Bulletin of Ukraine”. (2021, September). Retrieved from https://www.president.gov.ua/documents/4732021-40121.

[2] Order of the Ministry of Defense of Ukraine No. 484 "About Approval of the Order of the Organization and Implementation of Defense Planning in the Ministry of Defense of Ukraine, the Armed Forces of Ukraine and other Components of Defense Forces". (2020, December). Retrieved from https://zakon.rada.gov.ua/laws/show/z0196-21\#Text.

[3] Rusnak, I. (Ed.). (2021). White book 2019-2020. Armed Forces of Ukraine. State Special Transport Service. Vinnytsia: Vinnytska oblasna drukarnia.

[4] Us, S.A., \& Koriashkina, L.S. (2014). Models and methods of decision making. Dnipro: DUT.

[5] Cheng, Y.M., \& Lau, C.K. (2014). Slope stability analysis and stabilization: New methods and insight. Boca Raton: CRC Press.

[6] Berzin, E.A. (1974). Optimal resource allocation and elements of systems synthesis. Moscow: Sovetskoye radio.

[7] Pyatibratov, A.P., Gudyno, L.P., \& Kirichenko, A.A. (2004). Computing systems, networks and telecommunications. Moscow: Finansy i statistika.

[8] Blahun, I.S., Kichor, V.P., Feshur, R.V., \& Vorobets, C.Y. (2011). Mathematical methods in economics. Ternopil: Navchalna knyha - Bohdan.

[9] Hryhorkiv, V.S. (2011). Optimal management in the economy. Chernivtsi: ChNU.

[10] Pemberton, M., \& Rau, N. (2015). Mathematics for economists ( $4^{\text {th }}$ ed). Manchester: Manchester University Press.

[11] Dowling, E.T. (2001). Introduction to mathematical economics ( $3^{\text {rd }}$ ed.). New York: McGraw-Hill Companies.

[12] Boyko, N., Mochurad, L., Stetsiv, I., \& Kryvenchuk, Yu. (2020). Modeling of the information system for processing of a large distilled data for the investigation of competitiveness of enterprises. Proceedings of the $4^{\text {th }}$ International Conference on Computational Linguistics and Intelligent Systems, 1, 964-978.

[13] Musiy, N., \& Orlovska, A. (2018). Optimization methods of resources formation of enterprise industrial activity. Modern Economics, 8, 120-125.

[14] Mutanov, G. (2015). Mathematical methods and models in economic planning, management and budgeting (2 $2^{\text {nd }}$ ed.). Berlin: Springer.

[15] Pirogov, D., Danilko, V., Bala, V., \& Yakovenko, Y. (2020). The use of mathematical methods in the study of socioeconomic processes. Efektyvna Ekonomika, 12. Retrieved from http://www.economy.nayka.com.ua/?op=1\&z=8416. 


\title{
Методика раціоналізації розподілу \\ обмежених матеріальних ресурсів з урахуванням важливості і початкового стану забезпеченості об'єктів призначення

\author{
Володимир Вікторович Герасименко, Юлія Олександрівна Луцик, \\ Павло Петрович Пархоменко, Олександр Миколайович Деменєв, \\ Володимир Іванович Мірненко
}

\author{
Національний університет оборони України імені Івана Черняховського \\ 03049, просп. Повітрофлотський, 28, м. Київ, Україна
}

\begin{abstract}
Анотація. Організація ресурсного забезпечення потреб Збройних Сил України є важливим повсякденним завданням, що пов'язане з розподілом матеріальних засобів за об'єктами призначення. За умови достатньої ресурсної бази та другорядності чинників часу, швидкості, черговості постачання засобів, ресурсне забезпечення здійснюється за принципами «за потребою» і «за можливістю». Однак у практиці ресурсного забезпечення потреб Збройних Сил України з урахуванням обмежених ресурсних можливостей національної економіки, і інших подібних завдань, як правило, доводиться діяти в умовах кількісних і якісних обмежень ресурсної бази, i, до того ж, в умовах вимог до скорочення часу здійснення ресурсного забезпечення з урахуванням пріоритетності об'єктів призначення ресурсів, різного рівня їхньої початкової ресурсної забезпеченості. Метою статті $є$ пошук найкращого, раціонального i, навіть, оптимального за певними ознаками розподілу ресурсів за трьома варіантами умов діяльності: визначеність, невизначеність і ризик у прийнятті управлінських рішень. На підставі аналізу наявних методів нелінійного програмування в задачах розподілу, виходячи з умови збереження математичної коректності і доступності до практичного використання, в статті наведено порядок застосування методу максимального елементу. Запропонований підхід до оптимізації задачі розподілу розглянуто на прикладі можливих варіантів розподілу рівноефективних засобів ресурсу між об’єктами ресурсного забезпечення. Варіанти відрізняються значеннями важливості об’єктів і рівнями початкової забезпеченості у відносних одиницях на момент прийняття рішення щодо розподілу ресурсів у процесі ресурсного забезпечення деякого кінцевого завдання управління. Наведена в статті методика може застосовуватись у процесі планування та прийняття рішень, пов’язаних із розподілом ресурсів в організаційних системах військового та цивільного управління з урахуванням важливості та початкового стану забезпеченості об’єктів призначення у разі обмежених можливостей розпорядника ресурсу
\end{abstract}

Ключові слова: ресурсне забезпечення, пріоритетність об'єктів призначення, раціональний розподіл ресурсів, метод максимального елементу, планування 